\title{
Gastro-intestinal Parasites in Goat (Capra hircus) of Puranchaur VDC, Pokhara
}

\author{
Radha Purja, Mahendra Maharjan \\ Central Department of Zoology, Tribhuvan University, Kirtipur, Kathmandu, Nepal
}

*Corresponding Author: Mahendra Maharjan, Central Department of Zoology, Tribhuvan University, Kirtipur, Kathmandu, Nepal.

\begin{abstract}
The present study was conducted to assess the prevalence of gastrointestinal parasites of goat. A total of 220 fecal samples were collected of which 110 in summer and 110 in winter from Puranchaur VDC of Pokhara and examined by direct smear and flotation technique. The samples were collected in the month of January/February and June/July. A questionnaire survey was conducted among 100 farmers randomly regarding goat diseases and use of anthelmintics. Prevalence of protozoan and helminth were found to be $100 \%$ in goat. Altogether 13 genera of gastrointestnal parasites were found in the present study among the porotozoan, sporozoan (89.54\%) showed higher prevalence followed by sarcodina (31.81\%). Among helminth parasites, two were trematodes Fasciola sp. (8.18\%) and Paramphistomum sp. (4.09\%), 2 were cestodes Taenia sp. (4.09\%) and Moniezia sp.(18.18\%) and seven were nematode in which Toxocara sp. (68.18\%) showed the highest prevalence followed by Bunostomum sp. (35\%), Oxyuris sp. (30.45\%), Trichuris sp. (12.27\%), Strongyloides sp. (7.27\%), Trichostrongyloid sp. (5.45\%), Nematodirus sp. (4.54\%). During the study different type of parasitic infections were encountered in goats. Multiple infection was observed in 202 $(91.81 \%)$ samples and single infection in 18 (8.18\%) samples. Statistically there was no significant difference in the seasonal prevalence of gastrointestinal parasites during two seasons in goats. Most of the farmers were not aware of the gastrointestinal parasitic diseases. There should be awareness programme for farmers to enhance the goat farming and increase productivity.
\end{abstract}

Keywords: Goat; intestinal parasites; Bunostomum; Nepal; season

\section{INTRODUCTION}

The domestic goat is among the earliest animals domesticated by humans. They are distributed worldwide with higher concentrations in tropical areas and in dry zones (Di Cerboet al., 2010).Goats are primarily reared for meat and manure and regarded as the second important animal species (first being buffalo) for generating their cash income by farmers (Gatenby et al.,1990). As such the diseases of these animals are of great economic importance to humans.

Gastrointestinal parasitism is one of the most important diseases of goats, especially nematode infections which are among the major health problems limiting its pro-ductivity (Dimander et al., 2000 and Johannes et al., 2009). However, trematode (fluke) and cestode (tapeworm) parasites may also contribute to detrimental worm burdens in animals (Rahmann and Seip 2006). Protozoan diseases like amoebiasis, giardiasis, coccidiosis has been reported from different countries like Thailand, Costa Rica, India (Jittapalapong et al., 2011, Jimenez et al., 2007, Kaur and Kaur 2008) etc.Some of the common diseases of goats are viral diseases eg.foot and mouth diseases(Gibbens et al., 2001), blue tongue diseases (Conraths et al., 2009) and goat pox (Kitching 2003) etc. The goats also sufferes through various bacterial diseases e.g. pleuropneumonia (Thiaucourt and Bolske 1996) etc. funguses eg. facial ezyma (Phua et al., 2001)etc. Nutritional problems are the largest single cause of poor performance, particularly mineral and protein deficiences (Akerejola et al., 1979).

The prevalence of gastrointestinal helminths is related to the agro-climatic conditions like quantity and quality of pasture, temperature, humidity and grazing behavior of the host (Pal and Qayyum 1993). Seasonal prevalence of gastrointestinal parasites is higher during the warm-rainy season than in the dry-cold season. This might be related to the availability of browse and a longer browsing time 
in the warm-rainy season by the host (Pathak and Pal 2008) and sufficient moisture and temperature, which create favorable conditions allowing for the larval development, oocyst sporulation and survival of the infective stage larva (Faizal and Rajapakse, 2001). Furthermore, the increased browsing time increases the chance of contact between the host and parasites (Ouattara and Dorchies 2001).Higher infection during rainy season may also be attributed to suitable molarity of salt present in soil, an important factor for ecdysis (Soulsby 1966). Low prevalence in winter season may due to reduced grazing hours of the animals, which helps in reducing the chances of contact between host and parasites (Katoch, et.al.2000).

Economic losses are caused by gastrointestinal parasites in a variety of ways: they cause losses through lowered fertility, reduced work capacity, involuntary culling, a reduction in food intake and lower weight gains, lower milk production, treatment costs, and mortality in heavily parasitized animals (Lebbie 1994).

\section{MAterials ANd Methods}

The present study was carried out in goats of Puranchaur VDC of Pokhara. A total of 220 stool samples were collected of which 110 in summer and 110 in winter and preserved in $2.5 \%$ Potassium dichromate and the samples were transported to parasitology laboratory of Central Department of Zoology, Kirtipur, Kathmandu and examined by floatation and sedementation method for detection of gastrointestinal parasites of goats.

Flotation method is used widely for detecting eggs of nematodes and cestodes. As their eggs are lighter and small, they can float in the flotation liquid. Approximately $3 \mathrm{gm}$ of faecal sample was taken in a beaker and added $15 \mathrm{ml}$ of water then the sample was grinded lightly with the help of motor and pistle and filter the solution by tea strainer. The filtrate solution was poured into a centrifuge tube of $15 \mathrm{ml}$ and centrifuged at $1000 \mathrm{rpm}$ for 5 minutes. The tube's water was replaced with saturated sodium chloride solution and again centrifuged. After centrifuge more saturated sodium chloride solution was added to develop convex surface at the top of the tube and one drop of methylene blue (to stain) where a cover slip can be placed for a few minutes and then cover slip was removed and placed on a slide and examined at 10X and 40X. Photographs of cyst, eggs and parasites were taken and identified based on egg's color, shape, and size.

Sedimentation method is used for detecting trematodes eggs as they are but heavier than the other eggs. Saturated salt solution was removed gently from the test tube after examined the flotation portion and pour the sediment content into the watch glass and stirred the content gently to mixed it. One drop from the mixture was taken to prepare a second slide. The specimen was stained with iodine wetmounts solution.

In this way two slides were prepared from one sample (one from flotation and one from sedimentation) were examined under 10X and 40X of microscope to detect eggs of helminthes and trophozoites or cyst of gastrointestinal protozoans. While identified by the size and shape of the cyst, egg and larva of the parasites along with published literature.

\section{RESULT}

Out of 220 stool samples examined 220(100\%) were found to be infected with one or many types of gastrointestinal parasites.

\section{Seasonal prevalence of protozoan parasites}

Among 110 samples examined each during winter and summer revealed maximum $78(70.90 \%)$ infection with Eimeria sp. without micropile compared to winter 65(59.09\%) but difference is not statistically significant $\left(\mathrm{x}^{2}=3.37, \mathrm{p}=.066\right.$, d.f=1). In case of Eimeria $\mathrm{sp}$. with micropile, maximum $55(50 \%)$ infection was revealed during summer than in winter with $48(43.63 \%)$. The difference in the prevalence was found to be insignificant $\left(\mathrm{x}^{2}=.89, \mathrm{p}=.344\right.$, d.f=1) (Figure 1).

Only one genera of Sarcodina i.e. Entamoeba sp. was observed during the study and the prevalence was found to be $70(31.81 \%$ ) out of 220 samples (Fig 1). The difference in the seasonal prevalence was found to be statically insignificant $\left(x^{2}=.08, p=.772\right.$, d.f $\left.=1\right)$. 


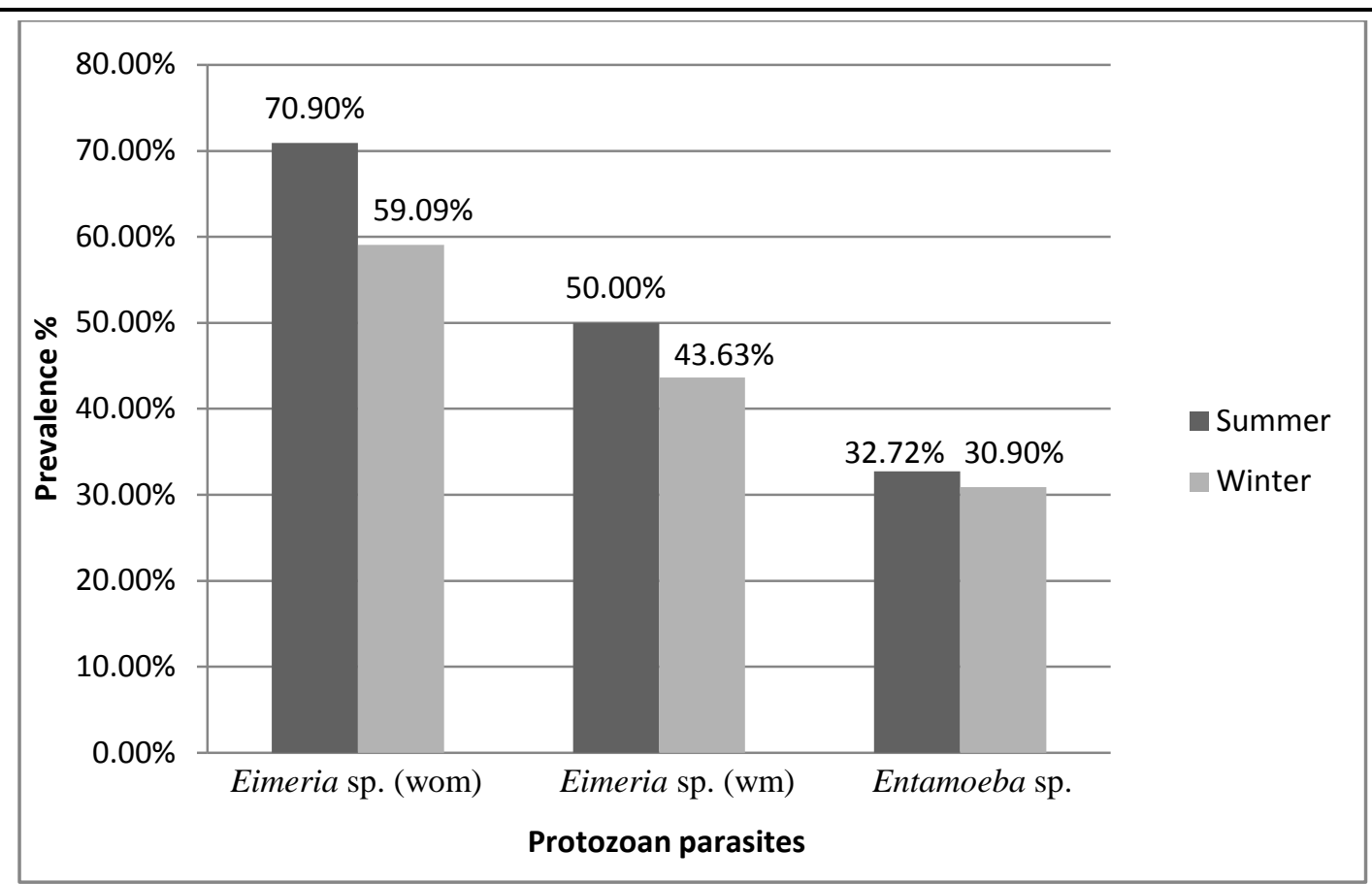

Figure 1. Seasonal Prevalence of Protozoan Parasites

Maximum (91.82\%) samples were found positive for nematode parasites followed by trematode $(12.27 \%)$ and cestode (22.7\%). Among them Toxocara sp. (68.18\%) showed the highest prevalence and lowest by Taenia sp. and Paramphistomum sp. i.e. (4.09\%). The seasonal prevalence of helminth parasite was higher in summer (95.45\%) than winter (88.18\%). (Figure 2).

Trematodes parasites

Two different genera of trematode parasites were observed infecting goats among $12.27 \%$ positive samples. Fasciola sp. (8.18\%) showed higher prevalence than Paramphistomum sp. (4.09\%). Difference in the seasonal prevalence of trematode parasites $\left(x^{2}=3.65, p=0.56, d . f=1\right)$, and Paramphistomum sp. $\left(\mathrm{x}^{2}=.00, \mathrm{p}=1.0, \mathrm{~d} . \mathrm{f}=1\right)$ was found statistically insignificant, whereas the difference was statistically significant for Fasciola sp. $\left(\mathrm{x}^{2}=4.6, \mathrm{p}=.031\right.$, d.f $\left.\mathrm{f}=1\right)$, in between two seasons. (Figure3).

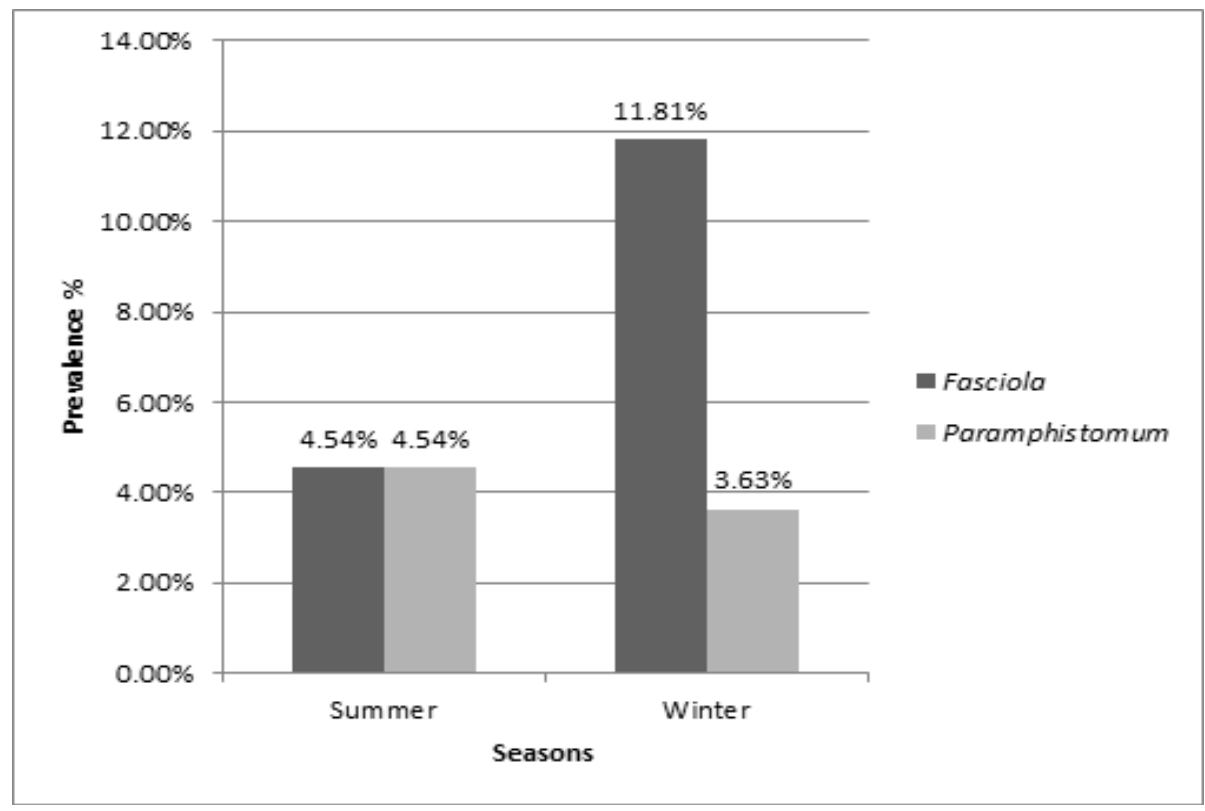

Figure 2. Seasonal prevalence of Trematode genera in goats

Cestodes parasites 
Out of 220 samples examined, the goats were found to be infected with two species of cestodes parasites (Moniezia sp. and Taenia sp.). The study showed a higher prevalence of Moniezia sp. (18.18\%) as compared to Taenia sp. (4.09\%).Statistically there was no significant difference in the seasonal prevalence of cestode parasites $\left(\mathrm{x}^{2}=.93, \mathrm{p} \leq .334\right.$, d. $\left.\mathrm{f}=1\right)$, Moniezia $\mathrm{sp} . \quad\left(\mathrm{x}^{2}=.47, \mathrm{p} \leq .493, \mathrm{~d} . \mathrm{f}=1\right)$ and Taenia sp. $\left(\mathrm{x}^{2}=.41, \mathrm{p} \leq .517, \mathrm{~d} . \mathrm{f}=1\right)$ respectively.(Figure 5)

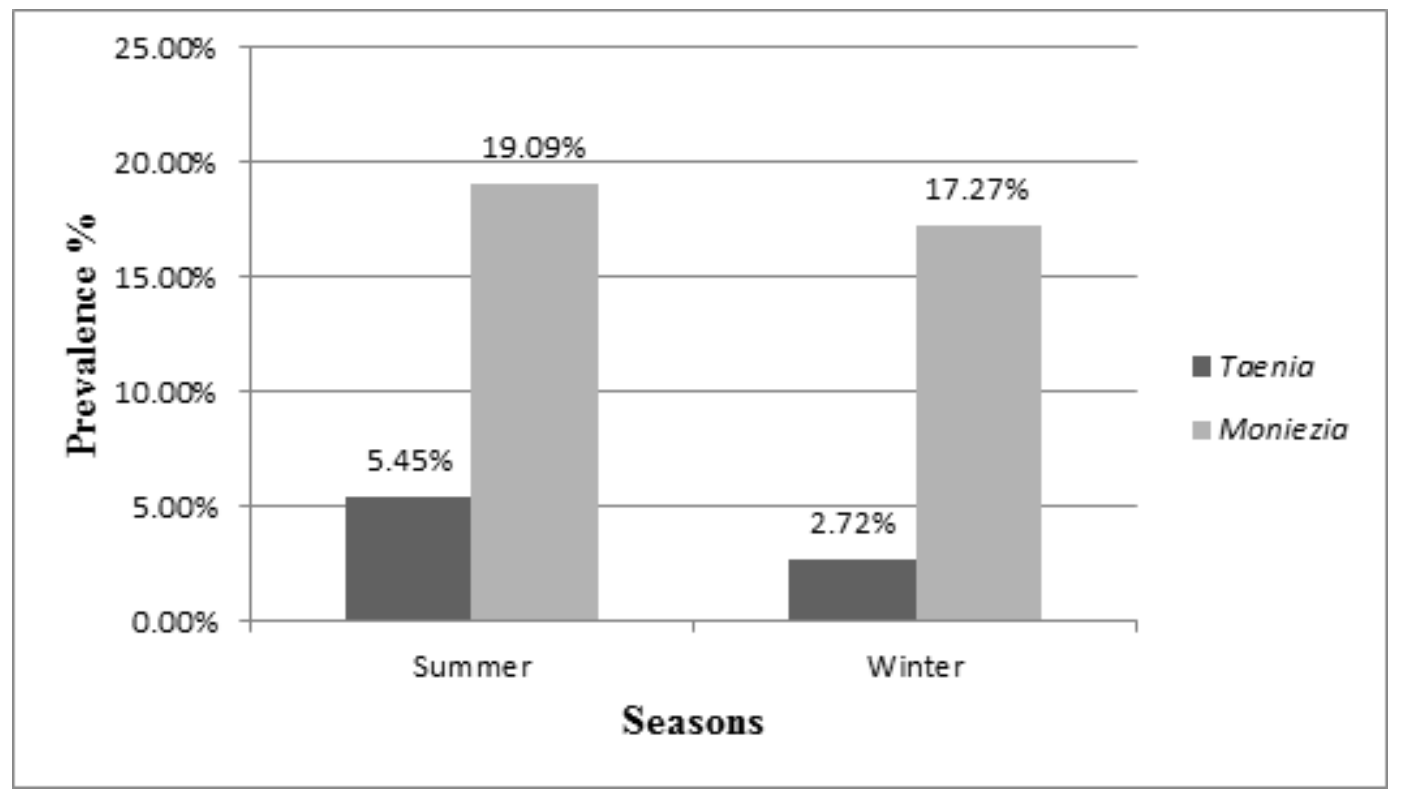

Figure 3. Seasonal prevalence of cestode genera in goats

\section{Nematode parasites}

A total of seven different nematode parasites were observed in $91.82 \%$ positive samples. Among them Toxocara sp. (68.18\%) was the most prevalent nematode in goats followed by Bunostomum sp. (35\%), Oxyuris sp. (30.45\%), Trichuris sp. (12.27\%), Strongyloides sp. (7.27\%), Trichostrongyloid sp. (5.45\%), Nematodirus sp. (4.54\%). Difference in seasonal prevalence of nematode parasite was statistically significant $\left(\mathrm{x}^{2}=6.37, \mathrm{p}=.012\right.$, d. $\left.\mathrm{f}=1\right)$. Parasitic association between summer and winter revealed insignificant for Bunostomum sp. Nematodirus sp. Oxyuris sp. Trichostrongyloid sp. and Strongyloides $\mathrm{sp}$. While there was significant association for Trichuris sp. and Toxocara sp.

Table 1. Seasonal prevalence of Nematode genera

\begin{tabular}{|l|l|l|l|l|}
\hline S/N & Name of genera & $\begin{array}{l}\text { Summer } \\
\mathbf{N}=\mathbf{1 1 0}\end{array}$ & $\begin{array}{l}\text { Winter } \\
\mathbf{N}=\mathbf{1 1 0}\end{array}$ & p value \\
\hline 1 & Bunostomum sp. & $34(30.09 \%)$ & $43(39.09 \%)$ & $\mathrm{p} \leq .867$ \\
\hline 2 & Nematodirus sp. & $6(5.45 \%)$ & $4(3.63 \%)$ & $\mathrm{p} \leq .517$ \\
\hline 3 & Oxyuris sp. & $35(31.81 \%)$ & $32(29.09 \%)$ & $\mathrm{p} \leq .884$ \\
\hline 4 & Trichostrongylus sp. & $4(3.63 \%)$ & $8(7.27 \%)$ & $\mathrm{p} \leq .235$ \\
\hline 5 & Strongyloides sp. & $8(7.27 \%)$ & $8(7.27 \%)$ & $\mathrm{p} \leq .604$ \\
\hline 6 & Trichuris sp. & $7(6.36 \%)$ & $20(18.18 \%)$ & $\mathrm{p} \geq .012$ \\
\hline 7 & Toxocara sp. & $91(82.72 \%)$ & $59(53.63 \%)$ & $\mathrm{p} \geq .000$ \\
\hline
\end{tabular}

During the study different type of parasitic infections were encountered in goats. Multiple infection $202(91.81 \%)$ was found to be higher than single infection $18(8.18 \%)$.

\section{DISCUSSION}

The present study was carried out to determine the seasonal prevalence of intestinal helminthes parasites of goats. It can be said that the prevalence of gastro intestinal parasites is considerably influenced by the climatic conditions and geographical factors. Generally the warm and humid conditions, Continuous high rainfall throughout the year which prevail in much of South-East Asia, provide good conditions for many gastro intestinal parasites to flourish that means there is no season during which the parasites are not a problem. (Tiyo et al., 2008).In the present study all the goats of Puranchaur V.D.C. were found to be infected with one or more species of gastro-intestinal parasites, 94.09\% samples were found to be infected with protozoan parasites where as $91.82 \%$ of the goats were found to be infected with helminth parasites. In present study, since oocyst were not cultured, 
species couldn't be identified hence Eimeria sp. has been broadly differentiated into two types (Eimeria with micropile and without micropile) on the basis of morphological structure.

Goats of Pokhara were found to be infected with 197 (89.54\%) of coccidian parasites which is higher in comparision to $27.1 \%, 50 \%, 57.5 \%$ and $22.4 \%$ revealed by Gupta and Chabra (1990) and Kaur and Kaur (2008), Rehman et al., (2011) and Gebeyehu et al., (2013) but lower than 93.7\% Jimenez et al., (2007) in goat and sheep of Costa Rica respectively. Infection with sarcoda parasites revealed $70(31.81 \%)$ positivity for Entamoeba sp. which is comparatively similar to $33.04 \%$ observed by (Jittapalapong et al., 2011) from Thailand, but higher than 1.84\% and 3.2\% recovered by (Radavelli et al.,2014) from Brazil and Tanzania (Mhoma et al., 2011). The trematodes observed in the goats of study area were Fasciola sp. and Paramphistomum sp. Fasciolopsis and paramphistomosis are two important parasitic diseases in farmed livestock all over the world where they causes huge losses to production (Wamae et al., 1998 and Mage et al., 2002).

Overall prevalence rate of cestodes in the current study was found to be 49(22.27\%). Among Cestodes, Moniezia sp. was observed in ruminants by Silvestre et al., (2000) in France, Waruiru et al.,(2005) from Kenya, and Gebeyehu et al., (2013) from Korea. The prevalence of Taenia sp. in goats of Pokhara was found to be (4.09\%) and this parasite has been reported in domestic animals by different researchers like Bashir (2009) in goats, Fakae (1990) in small ruminants, Edosomwan and Shoyemi (2012) in cattles and goats etc.

The overall prevalence of nematodes parasites in the goats at puranchaur V.D.C showed an infection rate of $91.82 \%$. This may be attributed to the temperature and climatic condition of the area, which are suitable for the development of endoparasites. The nematode parasites observed in the study were Bunostomum sp., Nematodirus sp., Oxyuris sp., Strongyloides sp., Trichostrongyloid sp., Trichuris sp. and Toxocara sp. The highest prevalence was shown by Toxocara sp.

\section{CONCLUSiON}

Goat farming is going popular in Nepal but lack of the commercial farming techniques still it is being practiced by using traditional and conventional methods from centuries. It could be the major cause of heavy economic losses among farmers. The overall prevalence of gastrointestinal parasites was found to be $100 \%$. From the present study it has been concluded that the gastrointestinal parasites in goats are highly prevalent in Puranchaur. Thirteen different genera of parasites were observed in the present study which are as follows protozoans; Eimeria sp. (89.54\%) and Entamoeba sp. (31.81\%) among trematodes ; Fasciola sp. (8.18\%) and Paramphistomum sp. (4.09\%) among cestodes; Taenia sp. (4.09\%) and Moniezia sp. (18.18\%) amongs nematodes; Bunostomum sp.(35\%), Nematodirus sp. (4.54\%), Oxyuris sp. (30.45\%), Trichostrongyloid sp. (5.45\%), Strongyloides sp.(7.27\%), Trichuris sp.(12.27\%)and Toxocara sp. (68.18\%) amongs nematodes. Among 13 genera Eimeria sp. showed the highest prevalence followed by Toxocara sp., Bunostomum sp., Entamoeba sp., Oxyuris sp. etc.

\section{ACKNOWLEDGEMENT}

We are greatly thankful to all the farmers who supported and contributed their valuable time for providing the samples. We like to express gratitude to Central Department of Zoology for allowing us in this study.

\section{REFERENCES}

[1] Akerejola, O.O., Van Veen, T.S., and Njoku, C.O. 1979. Ovine and caprine diseases in Nigeria: a review of economic losses. Bulletin of Animal Health and Production in Africa, 27(1): 65-70.

[2] Bashir, B.K. 2009.Seasonal prevalence of intestinal helminth parasites of goat (Capra hircus) of Khashi Bazaar, Kalanki Kathmandu. M.Sc.Thesis. Central Department of Zoology, Tribhuvan University, Kathmandu, Nepal.

[3] Conraths, F.J., Gethmann, J.M., Staubach, C., Mettenleiter, T.C., Beer, M. and Hoffmann, B. 2009. Epidemiology of bluetongue virus serotype 8, Germany.Emerging infectious diseases 15(3): 433.

[4] Di Cerbo, A.R., Manfredi, M.T., Zanzani, S. and Stradiotto, K. 2010. Gastrointestinal infection in goat farm in Lombardy (Northern Italy): Analysis on community and spatial distribution of parasites. Small Ruminants Research. 88: 102-112.

[5] Dimander, S.O., Hoglund, J., Sporndly, E., Waller, P.J. 2000. The impact of internal parasites on the productivity of young organically reared on semi-natural pastures in Sweden. Veterinary Parasitology 90: $271-284$ 
[6] Edosomwan, E.U. and Shoyemi, O.O. 2012.Prevalence of gastrointestinal helminth parasites of cattle and goats slaughtered at abattoirs in Benin City, Nigeria. African Scientist 13(2): 109-114.

[7] Faizal, A.C.M. and Rajapakse, R.P.V.J. 2001. Prevalence of coccidian and gastrointestinal nematode infection in cross breed goats in the dry areas of Sri Lanka. Small Ruminants Research 40: 233-238.

[8] Fakae, B.B. 1990. The epidiomology of helminthosis in small ruminants under the traditional husbandary system in eastern Nigeria. Veterinary Research Communication 14(5): 381-391.

[9] Gatenby, R. M., Shrestha, N. P. and Joshi, Y. R. 1990. The benefits of animal-keeping in the Koshi Hills. PAC Technical Paper-Pakhribas Agricultural Centre 24: 137.

[10] Gebeyehu, E.B., Seo, M.G., Jung, B.Y., Byun, J.W., Oem, J.G., Kim, H.Y. et al., 2013. Prevalence of gastrointestinal parasites in Korean native goats (capra hircus aegagrus). Journal of Animal and Plant Sciences 23(4): 986-989.

[11] Gibbens, J.C., Sharpe, C.E., Wilesmith, J.W., Mansley, L.M., Michalopoulou, E., Ryan, J.B. et al., 2001. Descriptive epidemiology of the 2001 foot-and-mouth disease epidemic in Great Britain: the first five months. The Veterinary Record, 149(24): 729-743.

[12] Gupta, S.K. and Chhabra, M.B. 1990. Inestinal Parasitic infections in young buffalo calves and anthelmintic treatment. Indian Veterinary Medical Journal 14(3): 194-197.

[13] Jimenez, A.E., Montenegro, V.M., Hernandez, J., Dolz, G., Maranda, L. and Galindo, J. 2007. Dynamics of infections with gastrointestinal parasites and Dictyocaulus viviparus in dairy and beef cattle from Costa Rica. Veterinary Parasitology 148(3-4): 262-271.

[14] Jittapalapong, S., Sangvaranond.A.,Nimsuphan, B., Inpankaew, T., Phasuk, C. and Pinyopanuwat, N. 2011.Prevalence of gastro-Intestinal parasites of dairy cows in Thailand. Journal of Natural Science 45: 40 -45 .

[15] Johannes, C., Johan, H., Georg, V.S.M., Pierre, D., Jozef, V. 2009. Gastrointestinal nematode infections in adult dairy cattle: Impact on production, diagnosis and control. Veterinary Parasitology 164: 70-79.

[16] Katoch, R., Chauhan, P.P.S. and Johri, D.K. 2000. Indian Veterinary. Journal 77: 259-260.

[17] Kaur, H., and Kaur, D. 2008. Prevalence of gastrointestinal parasites in domestic animals of Patiala and its adjoining areas. Journal of Veterinary Parasitology 22(2): 25-28.

[18] Kitching, R. P. 2002. Vaccines for lumpy skin disease, sheep pox and goat pox. Developments in biologicals 114: 161-167.

[19] Lebbie, S.H.B., Rey, B. and Irungu, E.K. 1994. Small ruminant research and development in Africa. Proceedings of the Second Biennial Conference of the African Small Ruminant Research Network. International Livestock Centre for Africa (ILCA): 1-5.

[20] Mage, C., Bourgne, H., Toullieu, J. M., Rondelaud, D., and Dreyfuss, G. 2002. Fasciola hepatica and Paramphistomum daubneyi: changes in prevalences of natural infections in cattle and in Lymnaea truncatula from central France over the past 12 years. Veterinary Research 33(5): 439-447.

[21] Mhoma, J.R.L., Kanyari, P.W.N. and Khagira, J.M. 2011. The prevalence of gastrointestinal parasites in goats in urban and peri- urban areas of Mwanza City, Tanzania. Science Parasitology 12(4): 191-196.

[22] Ouattara, L. and P. Dorchies 2001. Gastro-intestinal helminths of sheep and goats in subhumid and sahelian areas of Burkina Faso. Revue Medecine Veterinaire France 152: 165-170.

[23] Pal, R.A. and M. Qayyum. 1993. Prevalence of gastrointestinal nematodes of sheep and goats in upper Punjab, Pakistan. Pakistan Veterinary Journal 13: 138-141.

[24] Pathak, A. K., and Pal, S. 2008. Seasonal prevalence of gastrointestinal parasites in goats from Durg district of Chhattisgarh. Veterinary World 1(5): 136-137.

[25] Phua, S.H., Dodds, K.G., Morris, C.A., Paterson, K.A., McEwan, J.C., Garmonsway, sH. G. 1999. Catalase gene is associated with facial eczema disease resistance in sheep. Animal genetics 30(4): 286-295.

[26] Radavelli, W.M., Pazinato, R., Klauck, V., Volpato, A., Balzan, A and Rossett, J. 2014. Occurrence of gastrointestinal parasites in goats from the Western Santa Catarina, Brazil. Brazil Journal Veterinary Parasitology 23(1): 101-104.

[27] Rehman, T.U., Khan, M.N., Sajid, M.S., Abbas, R.Z., Arshad, M. Iqbal, Z. et al., 2011. Epidemiology of Eimeria and associated risk factors in cattle of district Toba Tek Singh, Pakistan. Parasitology research 108(5): 1171-1177.

[28] Rahmann, G. and Seip, H. 2006. Alternative strategies to prevent and control endoparasite diseases in organic sheep and goat farming systems-a review of current scientific knowledge. Ressort forschung fur den Okologischen Landbau 2006: 49-90.

[29] Silvestre, A., Chartier, C., Sauve, C. and Cabaret, J. 2000. Relationship between helminth species diversity, intensity of infection and breeding management in dairy goats. VeterinaryParasitoglogy 94(1-2): 91-105. 
[30] Soulsby, E.J.L. 1966. Biology of Parasites. Academic Press, New York and London. 185-196.

[31] Thiaucourt, F., and Bolske, G. 1996. Contagious caprine pleuropneumonia and other pulmonary mycoplasmoses of sheep and goats. Revue scientifiqueet technique International Office of Epizootics 15(4): 1397-1414.

[32] Tiyo, R., Guedes, T.A., Falavigna, D.L.M. and Falavigna-Guilherme, A.L. 2008. Seasonal contamination of public squares and lawns by parasites with zoonotic potential in southern Brazil. Journal of helminthology 82(01): 1-6.

[33] Wamae, L.W., Hammond, J.A., Harrison, L.J.S., and Onyango-Abuje, J. A. 1998. Comparison of production losses caused by chronic Fasciola gigantica infection in yearling Friesian and Boran cattle. Tropical animal health and production 30(1): 23-30.

[34] Waruiru, R.M., Otieno. R.O. and Mutune, M.N. 2005. Gastro-intestinal parasitic infections of sheep and goats in semi-arid areas of Machakos district, Kenya. Bulletin of animal health and production in Africa 53: $25-34$.

Citation: R. Purja, M. Maharjan, " Gastro-intestinal Parasites in Goat (Capra hircus) of Puranchaur VDC, Pokhara", International Journal of Research Studies in Zoology, vol. 3, no. 4, p. 39-45, 2017. http://dx.doi.org/10.20431/2454-941X.0304005

Copyright: () 2017 Authors. This is an open-access article distributed under the terms of the Creative Commons Attribution License, which permits unrestricted use, distribution, and reproduction in any medium, provided the original author and source are credited. 